\title{
Prevalence and risk factors of overweight and obesity: findings from a cross-sectional community-based survey in Benin
}

\author{
Akpa R. Gbary ${ }^{1 *}$, Alphonse Kpozehouen², Yessito C. Houehanou ${ }^{3}$, François Djrolo ${ }^{4}$, Murielle PG Amoussou ${ }^{3}$, Yessouf Tchabi ${ }^{3}$, \\ Roger Salamon ${ }^{5}$ and Dismand S. Houinato ${ }^{6}$ \\ *Correspondence: gbaryakpa@yahoo.fr \\ CrossMark \\ $\leftarrow$ Click for updates \\ 'Associate Professor of Epidemiology/Public health, Regional Institute of Public Health Slave Route, Ouidah, Benin-University of \\ Abomey, Benin. \\ 2Biostatistician, Regional Institute of Public Health, Slave Route, Ouidah, Benin-University of Abomey, Benin. \\ ${ }^{3}$ National Programme Fight against Noncommunicable Diseases, Ministry of Health, Cotonou, Benin. \\ ${ }^{4}$ Professor of Diabetology, Faculty of Health Sciences, Cotonou, Benin. \\ ${ }^{5}$ Professor of Epidemiology, ISPED, University of Bordeaux 2, France. \\ ${ }^{6}$ Professor of Neurology and Epidemiology, Laboratory of Chronic and Neurological Diseases Epidemiology (LEMACEN) Faculty of \\ Health Sciences, Cotonou and National Programme for the Fight against Noncommunicable Diseases, Ministry of Health, \\ Cotonou, Benin.
}

\begin{abstract}
Background: Data on overweight and obesity in general population in Benin is scarce. This study aimed therefore to assess prevalence and risk factors of overweight and obesity in Benin.

Methods: The study consisted of a cross-sectional survey, using the World Health Organisation (WHO)'s instrument for stepwise surveillance (STEPS) of non-communicable diseases risk factors. A five stage random sample of 25 to 64 years old male and female adults living in Benin participated in structured interviews and their size, weight and blood pressure were measured according to standardized procedures. Prevalence and means were computed with their 95\% confidence interval and standard error respectively, taking into account the sampling design. Prevalence was compared by Khi2 and means by Student's t test. Univariate and stratified by gender multivariate polytomous logistic regressions were performed to identify socio-demographic and physical risk factors of overweight and obesity.

Results: A total of 6,773 adults participated in the study. About $50.50 \%$ of the participants were male. The overall prevalence of overweight and obesity was $19.20 \%(95 \%$ CI $17.91 ; 20.66)$ and $7.25 \%(95 \%$ CI $6.34 ; 8.14)$ respectively. The prevalence of high risk abdominal obesity was $15.48 \%$ (95\% CI 15.45; 15.50). The prevalence of overweight $(22.41 \%$ vs. $15.99 \%)$ and obesity (10.68\% vs. $3.61 \%)$ was significantly higher in females than males. Likewise, the prevalence of abdominal obesity was significantly higher in women $(27.39 \%)$ than in men $(2.73 \%)$. After controlling for confounding factors, risk factors of overweight and obesity in both women and men were older age, primary and high school/university education levels, occupation, dwelling and department.

Conclusion: Our findings suggested that overweight and obesity are common in Benin. However, some differences were noted between women and men as regards socio-demographic variables. These findings call for more in-depth studies. Moreover, policies and programmes targeting the identified risk factors and high risk abdominal obesity may prove helpful in reducing the prevalence of overweight and obesity in Benin.
\end{abstract}

Keywords: Prevalence, risk factors, overweight, obesity, Benin

\section{Background}

In most of the African developing countries, attention is focused on communicable diseases mainly HIV/AIDS and malaria. As a result, non-communicable diseases are mostly neglected in spite of the growing concern caused by the rise of their prevalence. For instance, prevalence of overweight and obesity has been steadily increasing [1-3]. Many studies have shown the link between excess body weight and increased risk for cardiovascular disorders, [4] type 2 diabetes, dyslipidemia, some cancers and gallbladder diseases [5-7]. Prevalence of obesity and overweight is gradually increasing in developing countries as people experience changes in diet and physical activities patterns due to the influence of the western culture $[\mathbf{2}, \mathbf{8}]$.

According to the World Health Organisation report, more than one third of women and a quarter of men in Africa are overweight, and these proportions are expected to increase by $41 \%$ and $30 \%$ respectively over the next ten years. Recent trends in urbanization in developing countries and the globalization of the food market contribute in changing people's behaviour and lifestyle. Changes in lifestyle, associated with the nutrition transition from traditional to modern habits, have led to the emergence and progression of overweight and obesity [7,9]. 
Gbary et al. Global Epidemic Obesity 2014,

Besides, more emphasis was put on undernourishment and food security than obesity which was neglected [2]. Despite the importance of the issue, data on obesity and overweight in Africa in general and in Benin in particular is scarce. Indeed, the study by Sodjinou et al., [10] conducted in a random sample of 25 to 60 years old urban adults dealt only partially with obesity. Our study was entirely devoted to the issues of overweight and obesity. Its objective was to determine the prevalence and the risk factors of overweight and obesity in the communities in Benin using a cross-sectional survey.

\section{Methods}

\section{Context}

Benin is a Francophone country, located in West Africa. With a Gross National Product of 683US\$, Benin is one of the poorest countries in the world. According to the general population census of 2002, Benin population was estimated at $8,364,942$ people in 2008. People under 15 years old constitute $51 \%$ of the population and life expectancy is 59.2 years. Benin is divided into 12 departments which are subdivided into 546 districts. Districts are further divided into neighborhoods or villages. Main economic activities in Benin are agriculture, fishing, handicrafts and informal trade. The health system is organized on the model of primary health care with a central, intermediate and peripheral levels integrating all health programs [11].

\section{Study design and sampling}

The present study was a cross-sectional one of adults aged 25-64 years conducted on overweight and obesity risk factors in Benin using the WHO STEP instrument [12]. The sample size was calculated based on prevalence of hypertension of $27.8 \%$ [13] with the expected precision of $\pm 1.5 \%$. Each district selected was considered as a cluster. A cluster effect of 2 was therefore applied to the sample, as recommended by WHO for sociodemographic data [14]. Each cluster comprised of 114 individuals. A probabilistic sample of 6,853 adults aged from 25 to 64 was selected to participate in the study.

The probability proportional to size sampling was used to select the study sample [15]. Sixty of the 546 districts of Benin were randomly selected and smaller geographic units within the districts recognized as zones or villages were identified and listed for further random selection. The selection of individuals within each neighbourhood or village was based on Kish's method [16] which caters for gender and age. It has been done as follows: the investigator placed himself at the centre of the city or village and chose a random direction. In the chosen direction he numbered all the households, then selected the first household to be investigated. It was processed that way until the number of individuals in a given district was completed.

People having lived in the zone for at least six months and having given informed consent forms were included in the study. People unable and/or unwilling to respond to the questionnaire and pregnant women were excluded from the study.

\section{Data collection}

We used the WHO STEPS instrument [12] to collect data. The investigator performed a face to face structured interview using a questionnaire encompassing socio-demographic characteristics, behavioural habits and history of hypertension. Participants' blood pressure was then measured three times with a standard digital sphygmomanometer (Omron Healthcare, Inc., Bannockburn, III) while he/she was in a sitting position [12] after having rested for at least 15 minutes. The average of the last two readings was used in the analysis. Subjects were considered to have hypertension if their systolic blood pressure was at least $140 \mathrm{~mm} \mathrm{Hg}$, their diastolic blood pressure was at least $90 \mathrm{~mm} \mathrm{Hg}$, or they were being treated for hypertension [17]. Weight and size of the respondents were measured during the investigation. Weight was measured with a precision of $100 \mathrm{~g}$ with electronic weight and the precision of size was 1 $\mathrm{cm}$. The body mass index (BMI) was calculated by dividing weight in kilograms by size in meters squared. Subjects were considered as underweight/undernourished having chronic energy deficiency if their BMI was lower than $18.5 \mathrm{~kg} / \mathrm{m}^{2}$; not overweight, if their BMI was higher than $18.5 \mathrm{~kg} / \mathrm{m}^{2}$ and lower than $25 \mathrm{~kg} / \mathrm{m}^{2}$, overweight if their BMI was equal to $25 \mathrm{~kg} / \mathrm{m}^{2}$ and lower than $30 \mathrm{~kg} / \mathrm{m}^{2}$ and obese if their BMI was equal to $30 \mathrm{~kg} / \mathrm{m}^{2}$ or higher. Abdominal obesity was defined as waist circumference of $\geq 102 \mathrm{~cm}$ in men and $\geq 88 \mathrm{~cm}$ in women based on criteria suggested by WHO [18]. Information on fruits and vegetables intake was collected through two items: the number of portions of fruits and vegetables equivalent to $80 \mathrm{~g}$ each taken and the number of days of intake per week. Surveyor helped the respondents by showing them a bowl and pictures depicting a portion of $80 \mathrm{~g}$. Intake of 5 portions of $80 \mathrm{~g}$ of fruits and/or vegetables each day was considered as sufficient and otherwise insufficient.

\section{Statistical analysis}

Complex survey analysis methods [14] were used to determine prevalence of obesity and overweight in each group, taking into account the sampling design and the sampling weight of each participant which was calculated as the inverse of the probability of selection of that particular participant. We hypothesized that overweight and obesity were associated to gender, age, education level, occupation, dwelling, fruits and/or vegetables intake and department. Univariate and multivariate analyses were performed using STATA 9.2 software (STATA Corp LP, College Station, Texas). The univariate analysis was carried out to evaluate each independent variable for its unadjusted association with overweight or obesity. All independent variables significantly associated to overweight or obesity $(p<0.05)$ were included in multivariate analysis using polytomous logistic regression to evaluate factors associated with overweight or obesity. The multivariate logistic regression 
Gbary et al. Global Epidemic Obesity 2014,

was done separately for women and men.

\section{Ethical considerations}

The authorization to perform the study was obtained from the Ministry of Health in Benin. The study objectives were clearly explained to participants who gave their informed consent. Data was processed anonymously and confidentially. Researchers kept their promise to widely disseminate the results of the study within health sector partners and the community.

\section{Results}

A total of 6,773 persons agreed to participate in the study: $3,353(49.5 \%)$ women and 3,432 (50.5\%) men. The response rate was therefore $98.83 \%$. Average age of the sample was 43.65 years [C195\% $(43.22 ; 44.07)]$. The average age for women was 44.84 years [Cl95\% $(44.24 ; 45.45)]$ and 42.39 years [ $C 195 \%$ $(41.80 ; 42.97)]$ for men. Nearly two thirds $(62.32 \%)$ of the sample were illiterate whilst only $12.17 \%$ benefited from high school or university training. Most of the subjects (78.68\%) were independent workers, 9.39\% housewives and 3.23\% civil servants. The majority of the subjects $(66.09 \%)$ lived in rural areas. Atlantique (13.01\%), Borgou (10.10\%) and Oueme $(10.03 \%)$ were the most represented departments in the sample (Table 1). The average BMI was $23.71 \mathrm{~kg} / \mathrm{m}^{2}$ [Cl95\% (23.47; 23.94)] for women and $22.56 \mathrm{~kg} / \mathrm{m}^{2}$ [Cl95\% (22.34; 22.77)] for men. Figure 1 displays distribution of BMI rates according to gender. Chronic energy deficiency was equivalent in men and women and normal weight was higher in men. Conversely, overweight and obesity were higher in women than in men. In the population, the crude prevalence of overweight and obesity was $19.31 \%$ [CI95\% $(17.93 ; 20.69)]$ and $7.28 \%$ [CI95\% $(6.37 ; 8.18)]$, respectively. We noticed $22.47 \%$ [C195\% (20.42; 24.53)] for overweight and $10.73 \%$ [CI95\% $(9.21 ; 12.26)]$ for obesity in women and $15.97 \%$ [Cl95\% $(14.17 ; 17.70)]$ for overweight and $3.63 \%$ [Cl95\% $(2.74 ; 4.52)]$ for obesity in men. Prevalence of low fruits and vegetables intake was $82.37 \%$.

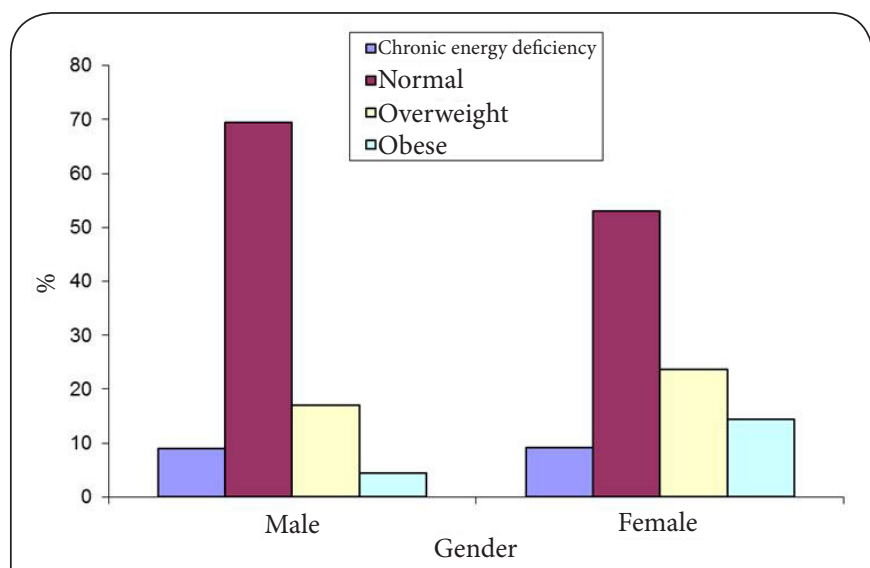

Figure 1. Body mass index (BMI) distribution according to gender in general population in Benin, 2008.
Prevalence of high blood pressure was 27.87\% (CI95\% 26.33\%; $29.41 \%$ ) and there was no significant difference between men (27.19\%) and women (28.51\%) $(\mathrm{p}=0.3996)$. The prevalence of overweight in women was significantly higher than in men $(p<0.001)$. The prevalence of obesity in women was threefold higher than in men $(10.74 \%$ vs. $3.63 \%$ and $p<0.001)$. Prevalence of abdominal obesity was significantly higher in women $(27.39 \%)$ than in men $(2.73 \%)(p=0.01)$.

Table 1 shows the results of the univariate analysis. Women were significantly more at risk of being overweight $(O R=1.68$; $p<0.001)$ or being obese than men $(O R=3.55 ; p<0.001)$. The risk of being overweight or obese significantly increased with age $(p=0.001)$.

The level of education was a risk factor for overweight and obesity ( $p=0.001$ ). Indeed, people with high school/university levels of education were significantly more at risk of being overweight $(O R=1.64 ; p<0.001)$ and obese $(O R=2.23 ; p<0.001)$ as compared to illiterate people. With regards to profession and as compared to civil servants, independent workers were less likely to be overweight $(p=0.001)$ or obese $(p=0.021)$. Apprentices, housewives and other professions were less likely to be overweight ( $p=0.017 ; p=0.039 ; p=0.001$ respectively). Housewives and other professions were less likely to be obese $(p=0.039$ and $p=0.002$ respectively). Fruits and vegetables intake was not significant factor for overweight $(p=0.777)$ or obesity ( $p=0.164)$. Living in urban areas was a risk factor to be overweight $(O R=1.95 ; p<0.001)$ or obese $(O R=3.24 ; p<0.001)$ as compared to people in rural areas. People living in Oueme were more likely to be overweight $(O R=1.82 ; p=0.006)$ or obese $(\mathrm{OR}=2.47 ; \mathrm{p}=0.038)$. People living in Littoral presented a higher risk of being overweight $(O R=3.08 ; p<0.001)$ or obese $(O R=4.98 ; p<0.001)$. People living in Collines were significantly more at risk of being overweight $(\mathrm{OR}=1.84 ; \mathrm{p}<0.004)$.

Multivariate analysis for women (Table 2) showed that age was a risk factor both for overweight and obesity. The risk of being overweight was significantly higher in the 55-64 years old age group $(\mathrm{OR}=1.40 ; \mathrm{p}=0.031)$. The risk of being obese was significantly higher in 35-44 years old age group ( $O R=1.95$; $\mathrm{p}=0.003)$, in $45-54$ years old age group $(\mathrm{OR}=2.43 ; \mathrm{p}=0.001)$ and in $55-64$ years old age group $(\mathrm{OR}=1.71 ; \mathrm{p}=0.015)$. Primary level education and high school/university education were risk factors for overweight $[(\mathrm{OR}=1.48 ; \mathrm{p}=0.017)$ and $(\mathrm{OR}=1.89$; $\mathrm{p}=0.021$ ) respectively]. The same situation was observed for obesity $[(O R=2.21 ; p<0.001)$ and $(O R=4.88 ; p<0.001)$ respectively]. Independent workers $(O R=0.29 ; p=0.010)$, housewives $(\mathrm{OR}=0.12 ; \mathrm{p}<0.001)$, unemployed people $(\mathrm{OR}=0.05$; $\mathrm{p}=0.012)$ and other professions $(\mathrm{OR}=0.06 ; \mathrm{p}=0.001)$ were significantly less likely to be overweight than civil servants. Likewise, independent workers $(O R=0.20 ; p=0.002)$, housewives $(O R=0.12 ; p<0.001)$ and others professions $(O R=0.01 ; p<0.001)$ were significantly less likely to be obese. The risk of being overweight $(O R=1.93 ; p<0.001)$ or obese $(O R=3.29 ; p<0.001)$ was significantly higher in women living in urban areas. The risk of being overweight was significantly higher in people 
Gbary et al. Global Epidemic Obesity 2014,

http://www.hoajonline.com/journals/pdf/2052-5966-2-3.pdf

doi: $10.7243 / 2052-5966-2-3$

Table 1. Unadjusted odds ratios for overweight and obesity in 25 to 64 years population in Benin in 2008: univariate analysis.

\begin{tabular}{|c|c|c|c|c|c|c|c|c|}
\hline \multirow[t]{2}{*}{ Characteristics } & \multirow[t]{2}{*}{ Total N (\%) } & \multicolumn{2}{|c|}{ Overweight or Obesity \% } & \multicolumn{4}{|c|}{ OR } & \multirow[t]{2}{*}{$\mathbf{P}$} \\
\hline & & Overweight & Obese & Overweight & $\mathbf{P}$ & Obese & $\mathbf{P}$ & \\
\hline Gender & & & & & & & & 0.0000 \\
\hline Male & $3420(50.49)$ & 15.97 & 3.63 & 1 & -- & 1 & -- & \\
\hline Female & $3353(49.51)$ & 22.48 & 10.74 & 1.68 & 0.000 & 3.55 & 0.000 & \\
\hline Age group & & & & & & & & 0.0000 \\
\hline $25-34$ & $2130(31.45)$ & 16.19 & 4.50 & 1 & -- & 1 & -- & \\
\hline $35-44$ & $1640(24.21)$ & 21.34 & 7.77 & 1.48 & 0.002 & 1.94 & 0.000 & \\
\hline $45-54$ & 1151(16.99) & 20.40 & 10.36 & 1.45 & 0.007 & 2.65 & 0.000 & \\
\hline $55-64$ & $1852(27.34)$ & 20.13 & 7.87 & 1.38 & 0.008 & 1.92 & 0.001 & \\
\hline Educational level & & & & & & & & 0.0000 \\
\hline Illiterate & $4224(62.37)$ & 18.14 & 6.63 & 1 & -- & 1 & -- & \\
\hline Primary level & $1725(25.47)$ & 21.02 & 7.51 & 1.22 & 0.063 & 1.19 & 0.258 & \\
\hline High school/University & $824(12.17)$ & 24.50 & 12.37 & 1.64 & 0.000 & 2.23 & 0.000 & \\
\hline Occupation & & & & & & & & 0.0023 \\
\hline Civil servant & $219(3.23)$ & 30.56 & 11.85 & 1 & -- & 1 & -- & \\
\hline Private Employee & $259(3.82)$ & 24.93 & 8.50 & 0.70 & 0.298 & 0.61 & 0.315 & \\
\hline Independent & $5329(78.68)$ & 18.67 & 7.20 & 0.47 & 0.001 & 0.47 & 0.021 & \\
\hline Apprentice & $21(0.31)$ & 31.13 & 3.94 & 0.90 & 0.877 & 0.29 & 0.116 & \\
\hline Student & $97(1.43)$ & 12.21 & 2.68 & 0.26 & 0.017 & 0.15 & 0.051 & \\
\hline Housewife & $636(9.39)$ & 21.58 & 6.55 & 0.56 & 0.039 & 0.44 & 0.039 & \\
\hline Retired & $110(1.62)$ & 20.22 & 13.60 & 0.57 & 0.167 & 0.99 & 0.998 & \\
\hline Unemployed & $49(0.72)$ & 18.83 & 4.94 & 0.46 & 0.219 & 0.31 & 0.102 & \\
\hline Other & $53(0.78)$ & 5.24 & 1.50 & 0.10 & 0.000 & 0.07 & 0.002 & \\
\hline Fruits and vegetables intake & & & & & & & & 0.3783 \\
\hline Yes & $5768(87.57)$ & 19.42 & 6.99 & 1 & -- & 1 & -- & \\
\hline No & $819(12.43)$ & 19.62 & 9.04 & 1.04 & 0.777 & 1.34 & 0.164 & \\
\hline Dwelling & & & & & & & & 0.0000 \\
\hline Urban & $2297(33.91)$ & 26.82 & 14.52 & 1.95 & 0.000 & 3.24 & 0.000 & \\
\hline Rural & $4476(66.09)$ & 17.83 & 5.85 & 1 & -- & 1 & -- & \\
\hline Departments & & & & & & & & 0.0000 \\
\hline Atacora & $566(8.36)$ & 14.71 & 4.46 & 1 & -- & 1 & -- & \\
\hline Atlantique & $881(13.01)$ & 18.68 & 7.16 & 1.42 & 0.108 & 1.91 & 0.127 & \\
\hline Alibori & $456(6.73)$ & 21.18 & 5.17 & 1.43 & 0.201 & 0.78 & 0.616 & \\
\hline Zou & $664(9.80)$ & 18.99 & 5.65 & 1.27 & 0.311 & 1.00 & 0.995 & \\
\hline Littoral & $565(8.34)$ & 29.14 & 20.58 & 3.08 & 0.000 & 4.98 & 0.000 & \\
\hline Mono & $339(5.01)$ & 19.68 & 8.81 & 0.954 & 0.886 & 0.94 & 0.906 & \\
\hline Oueme & 679(10.03) & 19.54 & 8.07 & 1.82 & 0.006 & 2.47 & 0.038 & \\
\hline Couffo & $572(8.45)$ & 19.27 & 6.19 & 1.31 & 0.210 & 1.39 & 0.519 & \\
\hline Collines & $565(8.34)$ & 18.03 & 13.40 & 1.84 & 0.004 & 2.33 & 0.059 & \\
\hline Borgou & $684(10.10)$ & 25.73 & 6.10 & 1.29 & 0.352 & 1.32 & 0.557 & \\
\hline Plateau & $461(6.81)$ & 17.03 & 5.78 & 0.92 & 0.727 & 0.71 & 0.463 & \\
\hline Donga & $341(5.03)$ & 17.90 & 5.16 & 1.02 & 0.996 & 0.71 & 0.460 & \\
\hline
\end{tabular}

living in Alibori $(O R=1.6 ; p=0.046)$, Littoral $[(O R=3.11 ; p<0.001)$ and Collines $(O R=2.21 ; p=0.001)$. The risk of being obese was significantly higher in Littoral $(\mathrm{OR}=7.63 ; \mathrm{p}=0.001)$ and in Collines $(\mathrm{OR}=4.21 ; \mathrm{p}=0.001)$. Multivariate analysis for men (Table 3 ) showed that the risk of being overweight in the 35-44 years old subjects $(O R=1.65 ; p=0.005)$ and the risk of being obese in the $35-44$ years old subjects $(O R=2.00 ; p=0.047)$ as well as in $45-54$ years old subjects $[(O R=2.86 ; p=0.004)$ were significantly higher than in the 25-34 years old subjects. As compared to illiterate people, the risk of being overweight was significantly higher in people with primary education $(O R=1.68 ; p=0.001)$ and people with high school/university education $(\mathrm{OR}=2.56 ; \mathrm{p}<0.001)$. The risk of being obese was significantly higher in people with high school/university education $(\mathrm{OR}=4.71 ; \mathrm{p}<0.001)$. Independent workers $(\mathrm{OR}=0.40$; $p=0.001)$, students $(O R=0.15 ; p=0.011)$, housewives $(O R=0.23$; 
Gbary et al. Global Epidemic Obesity 2014,

http://www.hoajonline.com/journals/pdf/2052-5966-2-3.pdf

doi: $10.7243 / 2052-5966-2-3$

Table 2. Adjusted odds ratios for overweight and obesity in 25-64 years old women in Benin in 2008: multivariate analysis.

\begin{tabular}{|c|c|c|c|c|c|c|c|c|}
\hline \multirow[t]{2}{*}{ Characteristics } & \multicolumn{4}{|c|}{ OR } & \multicolumn{3}{|c|}{ OR } & \multirow[b]{2}{*}{$\mathbf{P}$} \\
\hline & $\begin{array}{l}\text { Over } \\
\text { weight }\end{array}$ & IC & $95 \%$ & $\mathbf{P}$ & Obese & IC & $C_{95 \%}$ & \\
\hline Age group & & & & & & & & 0.0041 \\
\hline $25-34$ & 1 & -- & -- & -- & 1 & -- & -- & -- \\
\hline $35-44$ & 1.34 & 0.95 & 1.91 & 0.092 & 1.95 & 1.24 & 3.05 & 0.003 \\
\hline $45-54$ & 1.41 & 0.98 & 2.05 & 0.066 & 2.43 & 1.52 & 3.90 & 0.000 \\
\hline $55-64$ & 1.40 & 1.03 & 1.92 & 0.031 & 1.71 & 1.11 & 2.64 & 0.015 \\
\hline Education level & & & & & & & & 0.000 \\
\hline Illiterate & 1 & -- & -- & -- & 1 & -- & -- & -- \\
\hline Primary level & 1.48 & 1.07 & 2.05 & 0.017 & 2.21 & 1.49 & 3.27 & 0.000 \\
\hline $\begin{array}{l}\text { High school/ } \\
\text { University }\end{array}$ & 1.89 & 1.10 & 3.27 & 0.021 & 4.88 & 2.72 & 8.77 & 0.000 \\
\hline Occupation & & & & & & & & 0.0026 \\
\hline Civil servant & 1 & -- & -- & -- & 1 & -- & -- & -- \\
\hline $\begin{array}{l}\text { Private } \\
\text { employee }\end{array}$ & 0.39 & 0.10 & 1.56 & 0.184 & 0.39 & 0.09 & 1.83 & 0.236 \\
\hline Independent & 0.29 & 0.11 & 0.74 & 0.010 & 0.20 & 0.07 & 0.56 & 0.002 \\
\hline Apprentice & 0.34 & 0.05 & 2.22 & 0.257 & 0.09 & 0.01 & 1.08 & 0.058 \\
\hline Student & 0.70 & 0.12 & 4.27 & 0.701 & 0.37 & 0.04 & 3.55 & 0.386 \\
\hline Housewife & 0.32 & 0.12 & 0.86 & 0.023 & 0.12 & 0.04 & 0.37 & 0.000 \\
\hline Retired & 0.34 & 0.09 & 1.35 & 0.126 & 0.41 & 0.01 & 1.76 & 0.229 \\
\hline Unemployed & 0.05 & 0.02 & 0.51 & 0.012 & 0.20 & 0.02 & 2.26 & 0.194 \\
\hline Other & 0.06 & 0.01 & 0.32 & 0.001 & 0.01 & 0.01 & 0.10 & 0.000 \\
\hline Dwelling & & & & & & & & 0.000 \\
\hline Urban & 1.93 & 1.49 & 2.50 & 0.000 & 3.29 & 2.40 & 4.52 & 0.000 \\
\hline Rural & 1 & -- & -- & -- & 1 & -- & -- & -- \\
\hline Departments & & & & & & & & 0.0000 \\
\hline Atacora & 1 & -- & -- & -- & 1 & -- & -- & -- \\
\hline Atlantique & 1.01 & 0.58 & 1.73 & 0.970 & 1.66 & 0.83 & 3.30 & 0.152 \\
\hline Alibori & 1.6 & 1.01 & 2.68 & 0.046 & 1.36 & 0.63 & 2.92 & 0.436 \\
\hline Zou & 1.25 & 0.78 & 2.01 & 0.354 & 1.44 & 0.71 & 2.89 & 0.303 \\
\hline Littoral & 3.11 & 1.97 & 4.93 & 0.000 & 7.63 & 4.18 & 13.93 & 0.000 \\
\hline Mono & 1.34 & 0.77 & 2.34 & 0.303 & 1.85 & 0.82 & 4.15 & 0.138 \\
\hline Oueme & 1.00 & 0.60 & 1.60 & 0.984 & 1.94 & 1.00 & 3.76 & 0.05 \\
\hline Couffo & 1.03 & 0.62 & 1.69 & 0.905 & 1.20 & 0.58 & 2.51 & 0.321 \\
\hline Collines & 2.21 & 1.35 & 3.61 & 0.001 & 4.21 & 2.19 & 8.06 & 0.000 \\
\hline Borgou & 1.1 & 0.71 & 1.87 & 0.564 & 1.45 & 0.73 & 2.86 & 0.285 \\
\hline Plateau & 1.08 & 0.64 & 1.85 & 0.754 & 1.31 & 0.63 & 2.75 & 0.467 \\
\hline Donga & 1.66 & 0.98 & 2.82 & 0.059 & 1.68 & 0.77 & 3.69 & 0.194 \\
\hline
\end{tabular}

$p=0.001)$ and members of other professions $(O R=0.04 ; p=0.003)$ were significantly less likely to be overweight. Independent workers ( $\mathrm{OR}=0.29 ; \mathrm{p}=0.008)$ and students $(\mathrm{OR}=0.02 ; \mathrm{p}=0.001)$ were significantly less likely to be obese. The risk of being overweight ( $O R=2.07 ; p=0.001)$ or obese $(O R=3.56 ; p=0.001)$ was significantly higher in people living in urban areas. The risk of being overweight was significantly higher in Littoral $(\mathrm{OR}=2.41 ; \mathrm{p}=0.001)$, in Oueme $(\mathrm{OR}=1.74 ; \mathrm{p}=0.048)$ and Collines $(O R=2.06 ; p=0.008)$. Men in Littoral $(O R=3.97 ; p=0.001)$ and in Collines $(O R=2.76 ; p=0.029)$ were significantly at risk of being obese. No significant association was found for overweight in 8 departments and for obesity in 9 departments.
Table 3. Adjusted odds ratios for overweight and obesity in 25-64 years old men in Benin in 2008: multivariate analysis.

\begin{tabular}{|c|c|c|c|c|c|c|c|c|}
\hline \multirow[t]{2}{*}{ Characteristics } & \multicolumn{4}{|c|}{ OR } & \multicolumn{4}{|c|}{ OR } \\
\hline & $\begin{array}{l}\text { Over } \\
\text { weight }\end{array}$ & & $95 \%$ & $\mathbf{P}$ & Obese & IC & $95 \%$ & $\mathbf{P}$ \\
\hline Age group & & & & & & & & 0.0088 \\
\hline $25-34$ & 1 & -- & -- & -- & 1 & -- & -- & -- \\
\hline $35-44$ & 1.65 & 1.16 & 2.35 & 0.005 & 2.00 & 1.0 & 3.99 & 0.047 \\
\hline $45-54$ & 1.43 & 0.96 & 2.14 & 0.078 & 2.86 & 1.40 & 5.82 & 0.004 \\
\hline $55-64$ & 1.12 & 0.76 & 1.64 & 0.563 & 1.66 & 0.76 & 3.60 & 0.199 \\
\hline Education level & & & & & & & & 0.0000 \\
\hline Illiterate & 1 & -- & -- & -- & 1 & -- & -- & -- \\
\hline Primary level & 1.68 & 1.23 & 2.29 & 0.001 & 1.60 & 0.86 & 2.97 & 0.130 \\
\hline $\begin{array}{l}\text { High school/ } \\
\text { University }\end{array}$ & 2.56 & 1.81 & 3.61 & 0.000 & 4.71 & 2.42 & 9.17 & 0.000 \\
\hline Occupation & & & & & & & & 0.0001 \\
\hline Civil servant & 1 & -- & -- & -- & 1 & -- & -- & -- \\
\hline $\begin{array}{l}\text { Private } \\
\text { employee }\end{array}$ & 0.79 & 0.37 & 1.68 & 0.544 & 0.72 & 0.21 & 2.51 & 0.608 \\
\hline Independent & 0.40 & 0.23 & 0.69 & 0.001 & 0.29 & 0.11 & 0.73 & 0.008 \\
\hline Apprentice & 1.19 & 0.22 & 6.47 & 0.836 & 0.38 & 0.06 & 2.46 & 0.313 \\
\hline Student & 0.15 & 0.04 & 0.66 & 0.011 & 0.02 & 0.01 & 0.14 & 0.000 \\
\hline Housewife & 0.23 & 0.10 & 0.55 & 0.001 & 0.46 & 0.08 & 2.56 & 0.375 \\
\hline Retired & 0.55 & 0.21 & 1.49 & 0.245 & 0.97 & 0.24 & 3.82 & 0.964 \\
\hline Unemployed & 0.61 & 0.17 & 2.24 & 0.463 & 0.36 & 0.06 & 2.01 & 0.245 \\
\hline Other & 0.04 & 0.01 & 0.32 & 0.003 & 0.24 & 0.03 & 2.27 & 0.216 \\
\hline Dwelling & & & & & & & & 0.0000 \\
\hline Urban & 2.07 & 1.55 & 2.75 & 0.000 & 3.56 & 2.14 & 5.94 & 0.000 \\
\hline Rural & 1 & -- & -- & -- & 1 & -- & -- & -- \\
\hline Departments & & & & & & & & 0.0000 \\
\hline Atacora & 1 & -- & -- & -- & 1 & -- & -- & -- \\
\hline Atlantique & 1.53 & 0.84 & 2.79 & 0.162 & 0.46 & 0.16 & 1.33 & 0.155 \\
\hline Alibori & 1.20 & 0.69 & 2.08 & 0.515 & 0.79 & 0.25 & 2.45 & 0.695 \\
\hline Zou & 1.23 & 0.72 & 2.10 & 0.443 & 0.64 & 0.22 & 1.82 & 0.404 \\
\hline Littoral & 2.41 & 1.43 & 4.07 & 0.001 & 3.97 & 1.71 & 9.23 & 0.001 \\
\hline Mono & 1.28 & 0.62 & 2.63 & 0.496 & 1.94 & 0.67 & 5.59 & 0.215 \\
\hline Oueme & 1.74 & 1.02 & 3.04 & 0.048 & 1.08 & 0.38 & 3.02 & 0.881 \\
\hline Couffo & 1.35 & 0.79 & 2.33 & 0.267 & 1.39 & 0.54 & 3.56 & 0.484 \\
\hline Collines & 2.06 & 1.21 & 3.53 & 0.008 & 2.76 & 1.10 & 6.87 & 0.029 \\
\hline Borgou & 1.09 & 0.64 & 1.84 & 0.746 & 1.10 & 0.43 & 2.77 & 0.834 \\
\hline Plateau & 0.83 & 0.47 & 1.44 & 0.511 & 0.77 & 0.28 & 2.12 & 0.627 \\
\hline Donga & 0.72 & 0.37 & 1.39 & 0.334 & 0.36 & 0.07 & 1.84 & 0.224 \\
\hline
\end{tabular}

\section{Discussion}

Our study was based on the STEPS approach recommended by WHO for screening and surveillance of non-communicable diseases risk factors. The prevalence of obesity in our study is similar to that found in Congo (8.6\%) in 2004, Nigeria (8.8\%) $[19,20]$, Mauritius (10\%) [21], Algeria (9\%) [22] and it was consistent with the prevalence found by Abubakari et al., [20] in their meta-analysis. It is two times higher than in Eritrea (3.3\%) and half of the prevalence rate found in Cameroon (18\%) in 2004 [20]. A study in southern Morocco has reported a prevalence higher than our findings, 30\% for overweight and $49 \%$ for obesity [23]. The prevalence of obesity in the 
Gbary et al. Global Epidemic Obesity 2014,

Democratic Republic of Congo (5.7\%) [24] is lower than our findings. The dietary patterns specific to each country could explain the disparity in the prevalence rates of obesity. There is an increasing prevalence of obesity not only in industrialized countries but also in developing countries [25-29]. This is the case of Tanzania, where the prevalence of obesity increased from $3.6 \%$ in 1995 to $9.1 \%$ in 2004 [30].

As described in the literature, gender is a demographic factor associated with the prevalence of obesity. This trend was confirmed in our study. Indeed, a statistically significant difference was observed by gender. Thus, female subjects were significantly more obese than male. This difference was also found in several investigations in Tunisia [31], in Ghana in 2003 [32] and South Africa [33]. It could be related to the influence of cultural factors. Indeed, female obesity is seen as a sign of wealth and beauty in the African cultural context. Similarly, the influence of behavioural and psychosocial factors has been demonstrated to explain the importance of obesity in women [34]. Furthermore, it has also been reported in the literature that the prevalence of obesity and overweight increased with age $[35,36]$. This feature of the prevalence of overweight and obesity was confirmed in our study.

Prevalence of obesity was significantly associated with higher education in men as well as in women. Except for cultural factors discussed earlier, socioeconomic factors could explain this situation. Indeed, people with higher education represented only $12 \%$ of the study sample. Those people benefit usually from the best opportunities in public services and in private business, are wealthier, live in urban areas and adopt western way of life combined with a very low level of physical activities.

Prevalence of obesity was higher in urban than rural areas. A survey conducted in 2007 in urban Benin reported a prevalence of $18 \%$ [10]. The same observation was made in Eritrea in 2005 [37] and the Congo in 2007 [38]. The socioeconomic conditions in these countries do not favour the adoption of healthy behaviours and changes in lifestyle. In Benin, there is a tendency to have a diet rich in fat and low in fruits and vegetables.

Increasing urbanization and production patterns in Africa in general, and in Benin in particular are evolving towards the Western model. It involves a change in lifestyle with unbalanced meals, stress, decreased physical activity due to more sedentary occupations and the increasing use of motorized transport $[39,40]$. The inadequacy or lack of sports facilities in cities increased the population's settled way of life. Conversely, in rural areas, heavy physical labour is almost permanent and does not offer a lot of development opportunities and suitable periods of rest $[6,41]$. Such a situation may trigger the emergence of non-communicable diseases and pose a threat to sustainable health.

At the departmental level, the prevalence of obesity was higher in Littoral (20.38\%) than in Alibori (5.15\%), Atacora (4.45\%), and Donga (5.16\%). This difference could be explained by the fact that Littoral is more urbanized than Alibori, Atacora and Donga. These areas are mainly mountainous areas and people have different agricultural and diet habits. The Littoral department includes the economic capital of Benin, Cotonou, which is the most developed and where people's lifestyle is similar to the one in the Western world.

Hypertension and obesity are closely linked, but in our analysis, we did not consider hypertension as an associated factor to obesity, because in the literature it is not known exactly which of the two led to another [42]. However, we used hypertension to describe the population on which we worked. Indeed people who were overweighed or obese were at risk to have hypertension compared to normal people $(O R=1.53(p<0.001)$ and $O R=2.57(p<0.001)$ respectively). Dyer et al., Scholtee \& Stunkand, Stamler et al., showed the close relationship between hypertension and obesity or being overweight [43-45].

An obese person has the blood pressure higher than non-obese, which significantly increases the cardiovascular risk. We noticed this in our study, where the diastolic blood pressure's mean were $77.59 \mathrm{~mm} \mathrm{Hg}, 81.77 \mathrm{~mm} \mathrm{Hg}, 85.82 \mathrm{~mm}$ $\mathrm{Hg}$ for normal, overweight and obese respectively $(p<0.001)$; whereas their systolic blood pressure were $126.85 \mathrm{~mm} \mathrm{Hg}$, $132.17 \mathrm{~mm} \mathrm{Hg}, 137.60 \mathrm{~mm} \mathrm{Hg}$, respectively $(p<0.001)$.

A limitation of our study was the failure to consider consumption of alcohol and physical activity as independent variables. However, selected variables provided interesting insight into the features of overweight and obesity in Benin. The variables not included in the present study can be catered for in further studies in order to refine the findings.

\section{Conclusion}

Overweight and obesity are emerging in Benin, and they are more common in women than men. The independent determinants of overweight and obesity in men and women are aging, formal education, civil servant occupation, and urban residence. Prevention programs are needed to curb the rise of overweight/obesity in Benin.

\section{Competing interests}

The authors declare that they have no competing interests.

Authors' contributions
\begin{tabular}{|l|c|c|c|c|c|c|c|c|}
\hline Authors' contributions & ARG & AK & YCH & FD & MPA & YT & RS & DSH \\
\hline $\begin{array}{l}\text { Research concept and } \\
\text { design }\end{array}$ & $\checkmark$ & -- & $\checkmark$ & $\checkmark$ & -- & -- & -- & $\checkmark$ \\
\hline $\begin{array}{l}\text { Collection and/or } \\
\text { assembly of data }\end{array}$ & -- & -- & $\checkmark$ & -- & $\checkmark$ & $\checkmark$ & -- & $\checkmark$ \\
\hline $\begin{array}{l}\text { Data analysis and } \\
\text { interpretation }\end{array}$ & $\checkmark$ & $\checkmark$ & $\checkmark$ & - & -- & -- & -- & $\checkmark$ \\
\hline Writing the article & $\checkmark$ & $\checkmark$ & $\checkmark$ & $\checkmark$ & $\checkmark$ & $\checkmark$ & $\checkmark$ & $\checkmark$ \\
\hline $\begin{array}{l}\text { Critical revision of the } \\
\text { article }\end{array}$ & $\checkmark$ & $\checkmark$ & -- & - & - & - & $\checkmark$ & $\checkmark$ \\
\hline Final approval of article & $\checkmark$ & -- & -- & -- & -- & -- & -- & -- \\
\hline Statistical analysis & -- & $\checkmark$ & $\checkmark$ & -- & -- & -- & -- & -- \\
\hline
\end{tabular}




\section{Acknowledgement}

This study was technically and financially supported by the World Health Organization (WHO), Regional Office for Africa (AFRO). We are indebted to Mrs. Assamala Amoi, Editor/AFRO, who kindly reviewed the language of the manuscript. We sincerely thank Dr. Joses Kirigia, WHO/AFRO for his helpful advice. We express our deep gratitude to Professor Issifou Takpara, Honourable Minister of Health for his kind authorization to perform the study.

\section{Publication history}

Senior Editor: Alexandra Kautzky-Willer, Medical University of Vienna, Austria.

Received: 07-Feb-2014 Final Revised: 25-Mar-2014

Accepted: 27-Mar-2014 Published: 23-Apr-2014

\section{References}

1. Wickelgen I. Obesity: how big a problem? Science. 1998; 1364-1367.| Article

2. WHO. Obesity: Preventing and Managing the Global Epidemic. In. Geneva; 1998. I Website

3. Seidell JC. Time trends in obesity: an epidemiological perspective. Horm Metab Res. 1997; 29:155-8. | Article | PubMed

4. Stern M. Epidemiology of obesity and its link to heart disease. Metabolism. 1995; 44:1-3. | Article | PubMed

5. Bray GA. Health hazards of obesity. Endocrinol Metab Clin North Am. 1996; 25:907-19. | Article | PubMed

6. Despres JP, Lemieux I and Prud'homme D. Treatment of obesity: need to focus on high risk abdominally obese patients. BMJ. 2001; 322:716-20. | Article | PubMed Abstract | PubMed Full Text

7. Godfrey R and Julien M. Urbanisation and health. Clin Med. 2005; 5:13741. | Article | PubMed

8. Popkin BM. The nutrition transition in low-income countries: an emerging crisis. Nutr Rev. 1994; 52:285-98. | Article | PubMed

9. Popkin BM. An overview on the nutrition transition and its health implications: the Bellagio meeting. Public Health Nutr. 2002; 5:93-103. | Article | PubMed

10. Sodjinou R, Agueh V, Fayomi B and Delisle H. Obesity and cardiometabolic risk factors in urban adults of Benin: relationship with socio-economic status, urbanisation, and lifestyle patterns. BMC Public Health. 2008; 8:84. | Article | PubMed Abstract | PubMed Full Text

11. Institut national de la Statistique et de l'Analyse économique (INSAE). Rapport du 3ème Recensement Général de la Population et de l'Habitat au Bénin en 2002. In. Cotonou, Bénin; 2003.

12. Bonita $R$, de Courten $M$, Dwyer T, Jamrozik $K$ and Winkelmann $R$. Surveillance of risk factors for noncommunicable diseases: The WHO STEP wise approach. In. Geneva: World Health Organization; 2002. I Pdf

13. Akoha E. Prévalence de l'hypertension artérielle en population générale à Cotonou en 2007. Bénin, Cotonou; 2007.

14. Bennett S, Woods T, Liyanage WM and Smith DL. A simplified general method for cluster-sample surveys of health in developing countries. World Health Stat Q. 1991; 44:98-106. | Pdf | PubMed

15. WHO. The STEPwise approach to chronic disease risk factor surveillance (STEPS). Chronic diseases and health promotion. 2008. I Website

16. Berthier $\mathrm{C}$, Caron $\mathrm{N}$ and Neros $\mathrm{B}$. Le Kish : les problèmes de réalisation du tirage et de son extrapolation. Série Méthodologie Statistique. 1998.

17. Whitworth JA. 2003 World Health Organization (WHO)/International Society of Hypertension (ISH) statement on management of hypertension. J Hypertens. 2003; 21:1983-92. | Article I PubMed

18. WHO: Obesity: preventing and managing the global epidemic. In. Geneva; 2000.

19. Abubakari AR and Bhopal RS. Systematic review on the prevalence of diabetes, overweight/obesity and physical inactivity in Ghanaians and Nigerians. Public Health. 2008; 122:173-82. | Article | PubMed
20. Abubakari AR, Lauder W, Agyemang C, Jones M, Kirk A and Bhopal RS. Prevalence and time trends in obesity among adult West African populations: a meta-analysis. Obes Rev. 2008; 9:297-311. | Article | PubMed

21. Ministry of Health and Quality of Life. Mauritius Non-Communicable Diseases Survey 2004. In. Mauritius; 2004.

22. Ministère de la santé. Mesure des facteurs de risque des maladies non transmissibles dans deux wilayas pilotes en Algérie. In. Alger; 2005. | Pdf

23. Rguibi $M$ and Belahsen R. Overweight and obesity among urban Sahraoui women of South Morocco. Ethn Dis. 2004; 14:542-7. | Pdf | PubMed

24. Ministère de la Santé Direction de la lutte contre la maladie. Enquête sur les facteurs de risque des maladies non transmisibles à Kinshasa capital de la RD Congo selon l'approche STEPS de l'OMS. In. Kinshasa; 2006. | Pdf

25. Agyemang $C$, Owusu-Dabo E, de Jonge A, Martins D, Ogedegbe $G$ and Stronks K. Overweight and obesity among Ghanaian residents in The Netherlands: how do they weigh against their urban and rural counterparts in Ghana? Public Health Nutr. 2009; 12:909-16. | Article | PubMed

26. Cuong TQ, Dibley MJ, Bowe S, Hanh TT and Loan TT. Obesity in adults: an emerging problem in urban areas of Ho Chi Minh City, Vietnam. Eur J Clin Nutr. 2007; 61:673-81. | Article | PubMed

27. Gellner R and Domschke W. [Epidemiology of obesity]. Chirurg. 2008; 79:807-10. | Article | PubMed

28. Njelekela MA, Negishi $H$, Nara $Y$, Sato T, Tomohiro M, Kuga S, Noguchi T, Kanda T, Yamori M, Mashalla Y, Liu LJ, Ikeda K, Mtabaji J and Yamori Y. Obesity and lipid profiles in middle aged men and women in Tanzania. East Afr Med J. 2002; 79:58-64. | Article | PubMed

29. Siminialayi IM, Emem-Chioma PC and Dapper DV. The prevalence of obesity as indicated by BMI and waist circumference among Nigerian adults attending family medicine clinics as outpatients in Rivers State. Niger J Med. 2008; 17:340-5. | Article | PubMed

30. Villamor E, Msamanga G, Urassa W, Petraro P, Spiegelman D, Hunter DJ and Fawzi WW. Trends in obesity, underweight, and wasting among women attending prenatal clinics in urban Tanzania, 1995-2004. Am J Clin Nutr. 2006; 83:1387-94. | Article | PubMed

31. Belfaita L, Ben Alaya N, Gaigi $S$ and Delpeuch F. Le modèle causal Obésité en Tunisie. Options Méditérannéennes. 2002; 71-93. | Pdf

32. Amoah AG. Obesity in adult residents of Accra, Ghana. Ethn Dis. 2003; 13:S97-101. | PubMed

33. Armstrong ME, Lambert MI, Sharwood KA and Lambert EV. Obesity and overweight in South African primary school children -- the Health of the Nation Study. S Afr Med J. 2006; 96:439-44. | Pdf | PubMed

34. Amoah AG. Sociodemographic variations in obesity among Ghanaian adults. Public Health Nutr. 2003; 6:751-7. | Article | PubMed

35. Gerdes LU, Bronnum-Hansen H, Madsen M, Borch-Johnsen K, Jorgensen $\mathrm{T}$, Sjol A and Schroll M. Trends in selected biological risk factors for cardiovascular diseases in the Danish MONICA population, 1982-1992. J Clin Epidemiol. 2000; 53:427-34. | Article | PubMed

36. Marques-Vidal $P$, Ruidavets JB, Amouyel $P$, Ducimetiere $P$, Arveiler $D$, Montaye $\mathrm{M}$, Haas B, Bingham A and Ferrieres J. Change in cardiovascular risk factors in France, 1985-1997. Eur J Epidemiol. 2004; 19:25-32. | Article | PubMed

37. Mufunda J, Mebrahtu G, Usman A, Nyarango P, Kosia A, Ghebrat $Y$, Ogbamariam A, Masjuan $M$ and Gebremichael $A$. The prevalence of hypertension and its relationship with obesity: results from a national blood pressure survey in Eritrea. J Hum Hypertens. 2006; 20:59-65. I Article | PubMed

38. Kasiam Lasi On'kin JB, Longo-Mbenza B, Nge Okwe A and Kangola Kabangu N. Survey of abdominal obesities in an adult urban population of Kinshasa, Democratic Republic of Congo. Cardiovasc J Afr. 2007; 18:300-7. | Pdf | PubMed

39. Mokhtar N, Elati J, Chabir R, Bour A, Elkari K, Schlossman NP, Caballero $\mathrm{B}$ and Aguenaou H. Diet culture and obesity in northern Africa. J Nutr. 
Gbary et al. Global Epidemic Obesity 2014,

2001; 131:887S-892S. | Article | PubMed

40. Musaiger $\mathrm{AO}$ and Al-Mannai MA. Weight, height, body mass index and prevalence of obesity among the adult population in Bahrain. Ann Hum Biol. 2001; 28:346-50. | Article | PubMed

41. Rguibi M and Belahsen R. Prevalence of obesity in Morocco. Obes Rev. 2007; 8:11-3. | Article | PubMed

42. Julius $S$, Valentini $M$ and Palatini P. Overweight and hypertension : a 2-way street? Hypertension. 2000; 35:807-13. | Article | PubMed

43. Dyer AR, Elliott $P$ and Shipley M. Body mass index versus height and weight in relation to blood pressure. Findings for the 10,079 persons in the INTERSALT Study. Am J Epidemiol. 1990; 131:589-96. | PubMed

44. Scholtee $D$, Stunkand A. The effect of weight reduction on blood pressure of 302 obese patients. Arch Intern Med. 1990; 150:1701-1704.

45. Stamler R, Stamler J, Riedlinger WF, Algera G and Roberts RH. Weight and blood pressure. Findings in hypertension screening of 1 million Americans. JAMA. 1978; 240:1607-10. | Article | PubMed

\section{Citation:}

Gbary AR, Kpozehouen A, Houehanou YC, Djrolo F, Amoussou MPG, Tchabi Y, Salamon R and Houinato DS.

Prevalence and risk factors of overweight and obesity: findings from a cross-sectional community-based survey in Benin. Glob Epidemi Obes. 2014; 2:3.

http://dx.doi.org/10.7243/2052-5966-2-3 